\title{
Women Empowerment in The Tourism Sector ; Female Tour Guide in Egypt
}

Soha Bahgat Mohammed

\begin{abstract}
The objective of the paper is to investigate the problems that face female tour guides in Egypt to assure their empowerment. The results obtained from the analysis of questionnaires for travel agencies and female tour guides assures the empowerment of women in the field of tourism especially in tour guidance. The paper reveals that the problems faced by female tour guides in their career are not serious obstacles that prevent their work. Nevertheless, women in tour guidance had proven competency which might enable tour agencies to rely on them.

Key words: women empowerment, tourism sector, female tour guide, travel agency.
\end{abstract}

\section{Introduction}

The use of the term "empowerment" has firstly appeared in 1970's, until later in the 1990's when it was specifically applied to women and is today known as the "women empowerment". Generally, "empowerment" could be defined as the ability of individuals to make decisions which in return will enable them to participate in the political and economic spheres. In addition, "empowerment" implies that people are fully conscious about their own fields of interest which will enhance their chances in contributing to decision making. When the term is applied to women of a certain society, they are entailed with other implications: This is based on the fact how women stand on an equal footing with men. Moreover, it sheds light on their financial and economic independence in a way that does not necessarily mean that men are deprived of their important role in the society (Aminur Rahman, 2013). In addition, empowerment of women is one of multiple terms used to identify the status of women within the society which is defined as “women's power relative to men's in the households, communities, and nations in which they live". It actually entails that women would possess enough power that enables them to act effectively both within the household and in their community in general (Duffy et al, 2015). Empowerment of women is a clear sign of the development of nations. As it enables women themselves to be effective in their society, know their own targets and work and them to overcome any state of inequality in the community (Vujko et al, 2018). This actually goes in line with the Fifth Sustainable Goal initiated by the United Nations which is to achieve gender equality and empower women and girls. The core of women and girls empowerment and gender equality is mainly adopted to assure peaceful and sustainable future for the globe (UN portal, 2018).

The UNWTO and the UN Entity for Gender Equality and the Empowerment of Women believed that tourism could be one of the main tools used to achieve women's empowerment. According to the UNWTO research and statistics, women are regarded as the majority of the tourism sector work force all around the world. However, they are ranked as the lowest paid as well as handling the lowest categorized jobs.

Based on a study carried by the WBG "World Bank Group" in the MENA region, women are a minority in tourism employment with a gap between women and men in the field that is estimated at $53 \%$. Nevertheless, the WBG reports that tourism provides better opportunities for the employment of women and their empowerment than any other sector of economy.

\section{Literature review:}

\section{Women empowerment and the world tourism}

Many researches had focused on the fact that women are being discriminated and suffered from career issues only because of their gender. Despite the aforementioned facts, women play a vital role in the development of ecotourism especially in countries under development. This is because women actively and equally contribute to sustainable tourism (Scheyvens, 2000); based on the United Nations report on Sustainable Development (UN report, 1999). This global shift towards the empowerment of women through tourism is due to that the tourism sector could still provide women the financial stability they seek. In addition, it will affect the whole country with lowering the level of poverty and unemployment (AlSawafi, 2016).

Despite the fact that local societies are more likely to be centered on males who dominate the scene and make the best benefit of the tourism sector investments in the area, special attention is given to women's role in the tourism sector; especially sustainable and ecotourism, since in these local communities girls and women tend to have knowledge regarding the natural resources of their surrounding environment and how to get best use of it. The empowerment of women through ecotourism would assure their political, economic, psychological and social empowerment through the enhancement of their self-worth as well as their capability of earning their own income which will enable them to be effective members in their communities. However although women had benefited from several aspects of ecotourism; they are neglected for the favor of men in posts in eco-lodges or in tour guidance (Scheyvens, 2000) In some examples from around the world, women actually were empowered enough to start their own tourism business. Despite of facing many difficulties, women wanted to get over them so as to achieve their own financial independence. This idea of female entrepreneurship in the tourism field had proved its effectiveness in the development of society especially in the rural and small communities (Vujko, Tretiankova, Petrović and Radovanovic, 2018).

Many studies adopted several initiatives to investigate the case of immigrant women working in the tourism field. It was revealed that in migrant females were regarded as of low status and unqualified and thus they were handled the so-called gendered jobs such as receptionist and the housekeeper and given the lowest fares.

The status of women and their empowerment in the global tourism field could be attested through opinions of men in interviews. The majority of men had declared that when women get posts and earn their own income they became financially independent. What makes tourism a very important tool in the women's empowerment is the that the working hours of tourism could be flexibly changed to suit their household activities and also to be able to work for extra time and thereby. their own self-esteem and confidence due to their sense of making a difference in their household and society (Duffy, Kline, Mowatt, and Chancellor, 2015). In more conservative societies, women working in the tourism sector could still find themselves being viewed with rather negative implications. Research conducted on that specific point referred to several perceptions of the society toward women involved in the tourism business which might lead to the fact that they choose not to study tourism to avoid these negative connotations. Certain difficulties could face women in the conservative communities like working on holidays and over night 
shifts. Thus, the UNWTO and UN recommended in 2011 that specific rules ought to be regulated so as to assure the empowerment of women in the tourism sector. The most important of which is to facilitate and advance the maternity leave system and allow women to work in flexible hours from home (AlSawafi, 2016).

\section{Women in the Egyptian tourism sector}

According to the Global Report on Women in Tourism 2010, which was launched in March 2011, Egyptian women had suffered from gender discrimination in the tourism sector based on researches carried in this context. The whole percentage of women working the field hotels and restaurants reached $3.3 \%$ and they had a slightly higher income than their male workmates. Nevertheless, within the five-star hotels, women are less likely to attain high managerial posts. However, this is not the case in smaller hotels and resorts where they could reach top positions. Among the reasons of this career obstacle was the gender discrimination (Global Report on Women in Tourism 2010 issued by UNWTO and UN Women , 2011). Based on the report of ETF "European Training Foundation" in 2010 on Women and Work in Egypt, a survey was conducted in $61 \%$ of the tourism agencies in the country to investigate the status of women employment in the tourism sector. It shows that women form $10 \%$ of the employees of the tourism companies, where they form $15 \%$ in the high level managerial posts and $24 \%$ in middle managerial posts which is a considerably high proportion.

\section{The Egyptian women empowerment as tour guides}

Tour guidance is regarded as one of the most important jobs in the field of tourism that entails deep acquaintance with various aspects of knowledge and to which is very much attributed the success of the tourism industry (Abdel Azim et al, 2011). Women working in the field of tourism had to prove their potential and that they deserve their current posts. Based on the report of ETF "European Training Foundation" in 2010 on Women and Work in Egypt, women and girls are required to assure their academic knowledge and learning different languages to work in the tourism sector. They face numerous problems the most significant of which is the prejudice of the society regards the females working in tourism which could lead to the refusal of their family members and significant others to the concept of working in this career (Kärkkäinen , 2010). Nevertheless, the flexibility of the tour guidance profession might enable women to be able to work according to their own schedule. This is because; tour guidance is a freelance job whose employee could simply enjoy working with no official time restrictions as well as within the premises of their cities. Moreover, it enables females to assure their financial stability and earn a sufficient income (Kärkkäinen , 2010). The majority of women working in tourism stated that being a tour guide is regarded as the most suitable profession for them in the field (Kärkkäinen, 2010). Women working as tour guides not only have to focus on their educational background but also on developing their own personal skills; which for sure will affect the development of their personality on the long run. Research on the skills needed for Egyptian tour guides to achieve their work with professionalism has revealed that the personal abilities and competence of the tour guide is not less important than their information about the Egyptian art, history and other fields of civilization (El-Sharkawy, 2016).

\section{Research methods}

The sources of data used in the research are classified into two types: Secondary sources that includes books, articles and reports related to the research topic and Primary sources that includes the field study, where data were Collected by questionnaires targeting the travel agencies and the female tour guides.

The main study tool: In this part of the study, the research aims to know the credibility of the data that was analyzed by the "SPSS" system so as to identify to what extent the tour guidance profession is suitable for women beside knowing the exact reason behind the success or failure of females in the field of tour guidance. In addition, it targets to cuss the opinions of the tour agencies regarding the employment of women as tour guides. A number of 54

questionnaire forms were distributed to travel agencies and 40 to female tour guides, as shown in the following table:

\begin{tabular}{|c|c|c|c|}
\hline $\begin{array}{c}\text { Groups targeted by the } \\
\text { questionnaire forms }\end{array}$ & $\begin{array}{c}\text { The distributed } \\
\text { questionnaire forms }\end{array}$ & $\begin{array}{c}\text { Invalid questionnaire } \\
\text { forms }\end{array}$ & $\begin{array}{c}\text { The analyzed } \\
\text { questionnaires }\end{array}$ \\
\hline Travel Agencies & 54 & 6 & 48 \\
\hline Female tour guides & 40 & 4 & 36 \\
\hline
\end{tabular}

\section{Questionnaire forms validity:}

The validity of the questionnaire form is identified by its capability of completing and measuring the objectives of the study. The researcher was assured by the validity of the questionnaire by presenting it to the specialists in the field of tourism and tourist guidance. The researcher responded to the views of the specialists and to their amendments in the light of their proposals, and thus the form was finalized.

Results and discussion

First: Analysis of the survey form the targeted travel agencies to determine the suitability of tourism guidance as a profession for women(Table.1)

Table (1) Respondents' responses to the question of whether tourism guidance is a suitable for women.

\begin{tabular}{|c|c|c|c|}
\hline \multirow{3}{*}{ Valid } & Respondents answers & Frequency & Percent \\
\cline { 2 - 4 } & Yes & 42 & 87.5 \\
\cline { 2 - 4 } & No & 6 & 12.5 \\
\hline
\end{tabular}

Table (1) shows that $87.5 \%$ of respondents agree that tour guidance is suitable for women, while $12.5 \%$ of respondents do not agree.

Table (2): Respondents' responses to the question of whether the tourist agency prefer male or female for the tourist guidance profession.

\begin{tabular}{|c|c|c|c|}
\hline & Respondents answers & Frequency & Percentage \\
\hline \multirow{3}{*}{ Valid } & Male & 26 & 54.2 \\
\cline { 2 - 4 } & Female & 22 & 45.8 \\
\cline { 2 - 4 } & Total & 48 & 100.0 \\
\hline
\end{tabular}


Table (2) shows that $54.2 \%$ of the respondents prefer males in the field of tourist guidance, while $45.8 \%$ agree with the work of women in the same field.

Table (3) Respondents' responses to the question whether the type of tourist trip that is given to the tour guide depends on gender.

\begin{tabular}{|c|c|c|c|}
\hline \multirow{3}{*}{ Valid } & answers & Frequency & Percentage \\
\cline { 2 - 4 } & Yes & 20 & 41.7 \\
\cline { 2 - 4 } & No & 28 & 58.3 \\
\hline & Total & 48 & 100.0 \\
\hline
\end{tabular}

Table (3) shows that $41.7 \%$ of the respondents believe that male and female guides are nominated for tourist guidance based on the type of tourist trip, while $58.3 \%$ do not agree that the gender of the tourist guides are assigned to work according to the type of trip.

Table (4): Respondents' responses to the question whether there is a difference in the wage between women and men in the profession of tour guidance?

\begin{tabular}{|c|c|c|c|}
\hline \multirow{3}{*}{ Valid } & Respondents answers & Frequency & Percent \\
\hline & Yes & 20 & 41.7 \\
\cline { 2 - 4 } & No & 28 & 58.3 \\
\cline { 2 - 4 } & Total & 48 & 100.0 \\
\hline
\end{tabular}

Table (4) shows that $58.3 \%$ of respondents feel that there is no difference in the wage between males and females, while $41.7 \%$ of respondents feel difference. based on the interviews with the female tour guides that mentioned that some differences between income due to duration of the program tour which is not suitable sometimes for married female tour guides.

Table (5): Respondents' responses to the question whether the feedback of tourists regarding the tourist guide depends on their gender.

\begin{tabular}{|c|c|c|c|}
\hline & Respondents answers & Frequency & Percentage \\
\hline \multirow{3}{*}{ Valid } & Yes & 4 & 8.3 \\
\cline { 2 - 4 } & No & 44 & 91.7 \\
\cline { 2 - 4 } & Total & 48 & 100.0 \\
\hline
\end{tabular}

Table (5) shows that $91.7 \%$ of respondents feel that there is no difference in the feedback of tourists between male and female tourist guidance, while $8.3 \%$ see that there is a difference.

Table (6): Respondents' responses to the question of whether women face some troubles because of her work as a tourist guide.

\begin{tabular}{|l|c|c|c|}
\hline & Respondents answers & Frequency & Valid Percent \\
\hline \multirow{3}{*}{ Valid } & Yes & 43 & 89.6 \\
\cline { 2 - 4 } & No & 5 & 10.4 \\
\cline { 2 - 4 } & Total & 48 & 100.0 \\
\hline
\end{tabular}

Table (6) shows that $89.6 \%$ of the respondents believe that women face some troubles due to their work as tourist guide, while $10.4 \%$ do not believe so.

Table (7): Respondents' responses to the question of whether there is a turnover of women on the profession of tourism guidance?

\begin{tabular}{|l|c|c|c|}
\hline \multirow{3}{*}{ Valid } & Respondents answers & Frequency & Valid Percent \\
\hline \multirow{3}{*}{} & Yes & 14 & 29.2 \\
\cline { 2 - 4 } & No & 34 & 70.8 \\
\cline { 2 - 4 } & Total & 48 & 100.0 \\
\hline
\end{tabular}

From Table( 7) $70.8 \%$ of the respondents believe that women are looking to be in the profession of tourist guidance, while $29.2 \%$ believe that there is a demand for women's work in the field of tourist guidance.

Table (8): Respondents' responses to the question about the difficulties encountered by travel agencies in recruiting women in the profession of tourist guidance.

\begin{tabular}{|c|c|c|c|}
\hline \multirow{3}{*}{ Valid } & Respondents answers & Frequency & Percentage \\
\hline \multirow{3}{*}{} & Agree & 42 & 87.5 \\
\cline { 2 - 4 } & Neutral & 6 & 12.5 \\
\cline { 2 - 4 } & Total & 48 & 100.0 \\
\hline
\end{tabular}

From Table ( 8 ), $87.5 \%$ of respondents agree that there are some difficulties such as there commitments for their families and children, the working hours and traveling most of the time. such challenges affect women's work as a tourist guide, while $12.5 \%$ of respondents feel that there are challenges facing females in their work as tour guides.

Other findings of the study collected through the survey collections assured that the majority of respondents agree that there are social and familial challenges affecting women's employment as a tourist guides

Moreover, the respondents highlight that challenges includes working hours, travel most of the time and mobility that face women's work as tourist guides

Secondly: - Analysis of the survey form the targeted female tour guides to determine the suitability of tour guidance as a profession for women. The results were as follows: 
Table (1) Respondents' responses to the question Do you feel equal with colleagues in the field of tourist guidance?

\begin{tabular}{|l|c|c|c|}
\hline \multirow{3}{*}{ Valid } & Respondents answers & Frequency & Percentage \\
\hline & Yes & 31 & 86.1 \\
\cline { 2 - 4 } & No & 5 & 13.9 \\
\cline { 2 - 4 } & Total & 36 & 100.0 \\
\hline
\end{tabular}

Table 1 shows that $86.1 \%$ of respondents agree that there is equality between men and women in the profession of tourist guidance, while $13.9 \%$ of respondents do not agree.

Table (2) Respondents' responses to the question of whether the tourism agencies prefer male tour guides to females.

\begin{tabular}{|c|c|c|c|}
\hline \multirow{3}{*}{ Valid } & Respondents answers & Frequency & Valid Percent \\
\hline \multirow{3}{*}{} & Yes & 30 & 83.3 \\
\cline { 2 - 4 } & No & 6 & 16.7 \\
\cline { 2 - 4 } & Total & 36 & 100.0 \\
\hline
\end{tabular}

From table (2): $83.3 \%$ of the respondents agree that travel agencies prefer men guide due to aforementioned challenges that face women in the field such as family and children commitments, while $16.7 \%$ of respondents do not agree.

Table (3) Respondents' responses to the question of whether the type of tourist trip given to

the tour guide depends on gender.

\begin{tabular}{|l|c|c|c|}
\hline & Respondents answers & Frequency & Percentage \\
\hline \multirow{3}{*}{ Valid } & Yes & 31 & 86.1 \\
\cline { 2 - 4 } & No & 5 & 13.9 \\
\cline { 2 - 4 } & Total & 36 & 100.0 \\
\hline
\end{tabular}

Table (3) shows that $86.1 \%$ of the respondents agree that the type of tourist trip determines the gender of guide, while $13.9 \%$ of the respondents disagree.

Table (4) Respondents' responses to the question of whether there is a difference in wages between women and men in tourist guidance.

\begin{tabular}{|c|c|c|c|}
\hline & Respondents answers & Frequency & Percentage \\
\hline \multirow{3}{*}{ Valid } & Yes & 7 & 19.4 \\
\cline { 2 - 4 } & No & 29 & 80.6 \\
\cline { 2 - 4 } & Total & 36 & 100.0 \\
\hline
\end{tabular}

Table (4) shows that $19.4 \%$ of the respondents agree that there is a wage difference between women and men in tourist guidance, while $80.6 \%$ disagree.

Table (5) Response to the question of whether tour guidance is a difficult profession for women.

\begin{tabular}{|c|c|c|c|}
\hline & Respondents answers & Frequency & Percent \\
\hline \multirow{3}{*}{ Valid } & Yes & 18 & 50.0 \\
\cline { 2 - 4 } & No & 18 & 50.0 \\
\cline { 2 - 4 } & Total & 36 & 100.0 \\
\hline
\end{tabular}

From table (5), 50\% of the respondents disagree that there is difficulty for women in tourist guidance career, while $50 \%$ agree and think it is not suitable, usually it is because their marital and parental responsibilities require them to be present and limits their mobility and the ability to travel.

Table (6) Respondents' Responses to the: "Whether tourists prefer to have males over females as tour guide"

\begin{tabular}{|c|c|c|c|}
\hline & Respondents' Answers & Frequency & Percentage \\
\hline Valid & no & 36 & 100.0 \\
\hline & Total & 36 & \\
\hline
\end{tabular}

Table (7) Respondents' responses to the question of whether women face some challenges due to their work as a tour guide.

\begin{tabular}{|c|c|c|c|}
\hline & Respondents' Answers & Frequency & Percentage \\
\hline Valid & Yes & 36 & 100.0 \\
\hline & Total & 36 & \\
\hline
\end{tabular}

Table (7) shows that $100 \%$ of respondents agree that women face many challenges because tour guidance in their perspective is seen as an outgoing occupation where the woman is subject to many travels and this in the eyes of her family can be seen as a shortcoming.

Table (8) Respondents' Responses to question of whether female tour guides are proud .

\begin{tabular}{|l|c|c|c|}
\hline \multirow{3}{*}{ Valid } & Respondents' Answers & Frequency & Percentage \\
\hline \multirow{3}{*}{} & yes & 31 & 86.1 \\
\cline { 2 - 4 } & No & 5 & 13.9 \\
\cline { 2 - 4 } & Total & 36 & 100.0 \\
\hline
\end{tabular}

Table (8) shows that $86.1 \%$ of respondents feel proud of their work as tour guides, while $13.9 \%$ of respondents are not proud of their work as tour guides. The pride comes from the idea of having the freedom to travel and do what they love the most; traveling culture for solo women remains not accepted by most of the society. Women tour guides see themselves as warriors because they have to face many challenges in order to become a successful tour 
guide - for the single young women they have to convince their parents to travel alone and for the married they have to fulfill their duties.

Table (9) Respondents' Responses to question of whether they encourage any of their friends or family members to work in the field of tour guidance.

\begin{tabular}{|c|c|c|c|}
\hline \multirow{3}{*}{ Valid } & Respondents' Answers & Frequency & Percentage \\
\cline { 2 - 4 } & yes & 31 & 86.1 \\
\cline { 2 - 4 } & No & 5 & 13.9 \\
\cline { 2 - 4 } & Total & 36 & 100.0 \\
\hline
\end{tabular}

From table( 9 ) $86.1 \%$ of the respondents are proud to serve as guides and wish to nominate their friends and family members to work in the tourism guidance profession, while $13.9 \%$ of the respondents do not wish to encourage their friends and family members to work in tourist guidance.

Conclusion

It is that, the empowerment of women in the field of tourism and especially in tour guidance is actually possible. This is because the problems faced by female tour guides are not serious obstacles that prevent them from work. Nevertheless, women in tour guidance had proven competency which might enable tour agencies to rely on them.

The work conditions of tour guidance helps women to be able to balance between their careers. As tour guides and their family responsibilities, since tour guidance is a freelance job most of the time, it allows women to choose their working days, although it is seen as an obstacle to balance between work and family, this balance can be achieved with little compromises from both sides. Moreover, female tour guides proved that they are capable of being ambassadors and representatives of their country; they possess the necessary personal traits of the tour guides.

Recommendations

The study recommends to:

1. Organize awareness campaigns to change the social perception regarding the women working in the tourism industry and especially in tour guidance.

2. Motivate females to work in the field of tour guidance by organizing school trips and participating in activities that includes the role-play of a tour guide to acquaint them with the career.

3. Increase the percentage of women representing the board of tour guides syndicate to help solving the problems that face women in the sector.

4. Ensure the equality of pay between male and female tour guides.

References:

- Abdel Azim, T. S.; Kassem A. M. and Sanad H. S., (2011), Illegal Tour Guidance in Egypt Towards Developing a Scale for Evaluating the Performance. Third International Scientific Conference: Integrated Relational Tourism, Territories and Development in the Mediterranean Area, Helwan - Egypt, 24, 25, 26, October 2009, Conference Proceedings, Volume I, p. 93.

- AlSawafi A. M. (2016), Exploring the Challenges and Perceptions of Al Rustaq College of Applied Sciences Students towards Omani Women's Empowerment in the Tourism Sector. Tourism Management Perspectives 20, 247.

- Aminur Rahman, Md. (2013), Women's Empowerment: Concept and Beyond. Global Journal of Human Social Science, Sociology and Culture 13 (6), 1, 5.

- $\quad$ Duffy, L. D.; Kline, C.; Mowatt, R. A. and Chancellor, H. Ch. (2015), Women in Tourism: Shifting Gender Ideology in the DR. Annals of Tourism Research 52, 81.

- Global Report on Women in Tourism 2010 issued by UNWTO and UN Women, 2011, Madrid, Centro Español de Derechos Reprográficos, pp. 16, 32, 33.

- Scheyvens R. (2000), Promoting Women's Empowerment Through Involvement in Ecotourism: Experiences from the Third World. Journal of Sustainable Tourism 8 (3), 233

- $\quad$ United Nations Report, Commission on Sustainable Development, Seventh Session (1 May and 27 July 1998, and 19 30 April 1999), Economic and Social Council, Official Records, Supplement Nr. 9, New York, $1999,54$.

\section{Websites references:}

Vujko, Al., Tretiankova, T. N.; Petrović and Radovanovic, M., Women's empowerment through self-employment in Tourism, Annals of Tourism Research, 1; an online article in press, accessed from ScienceDirect portal https://07101mqfx-1103-y-https-www-sciencedirect-com.mplbci.ekb.eg/science/article/pii/S0160738318300951on November $19^{\text {th }}, 2018$ at $04: 13$ pm CLT.

- Women and Work in Egypt, Tourism and ICT Sectors: A Case Study, European Training Foundation Report 2010, (Kärkkäinen, O.)

https://www.almaany.com/ar/dict/ar-ar/, accessed on December $4^{\text {th }}, 2018$ at 07:30 pm CLT.

- http://www.sis.gov.eg/Story/108222?lang=en-us, accessed on November $2^{\text {nd }}, 2018$ at 04:30 pm CLT.

- https://www.un.org/sustainabledevelopment/gender-equality/, accessed on November $1^{\text {st }}, 2018$ at 07:50 pm CLT.

- $\quad$ http://www.wftga.org/tourist-guiding/what-tourist-guide, accessed on January $4^{\text {th }}, 2019$ at 08:45 pm CLT.

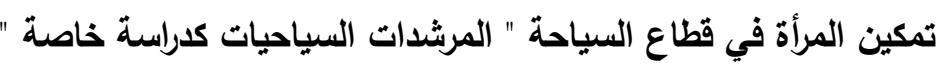

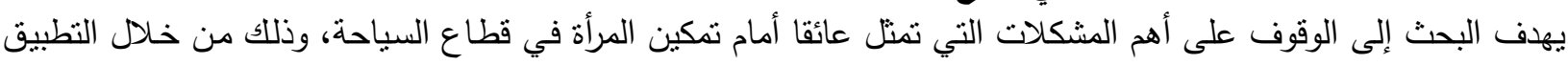
على المرشد السياحي كدراسة حالة.

تم تصميم استمارات استنيان (48) استمارة موزعة على الثركات الثرات السياحية لمعرفة آرائهم تجاه عمل المرأة كمرشدة سباحية. وكذا التحديات التي تحد من تمكينها في القيام بهذه المهنـة ـ كما تم تحليل (36) استمارة وزعت على المرشدات

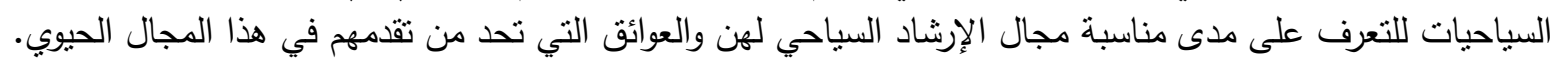

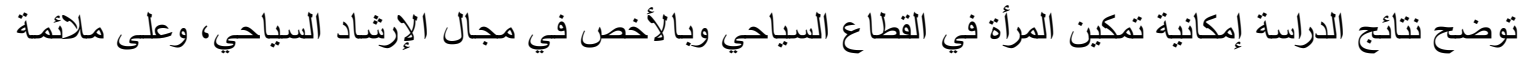

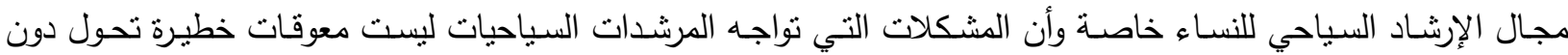

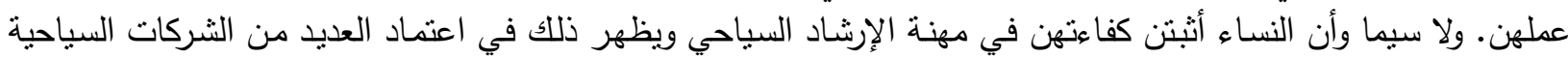

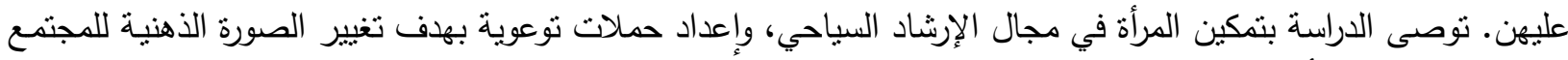
فيما يتعلق بعمل المرأة في القطاع السياحي ومنها مهنة الإرشاد السياحي. 